\title{
Black sand properties in beach-dune system, Patea Beach, North Island, New Zealand
}

\author{
Maciej DŁUŻEWSKI ${ }^{1, *}$, Mike HILTON², Andrzej MUSZYŃSKI ${ }^{3}$, Joanna ROTNICKA ${ }^{3}$ \\ and Barbara WORONKO ${ }^{4}$ \\ 1 University of Warsaw, Faculty of Geography and Regional Studies, Department of Geomorphology, Krakowskie \\ Przedmieście 30, 00-927 Warszawa, Poland \\ 2 University of Otago, School of Geography, PO Box 56, Dunedin 9054, New Zealand \\ 3 Adam Mickiewicz University in Poznań, Institute of Geology, Krygowskiego 12, 61-680 Poznań, Poland \\ 4 University of Warsaw, Faculty of Geology, Żwirki i Wigury 93, 02-089 Warszawa, Poland
}

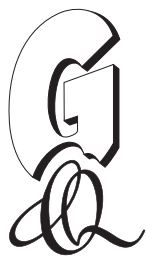

Dłużewski, M., Hilton, M., Muszyński, A., Rotnicka, J., Woronko, B., 2021. Black sand properties in beach-dune system, Patea Beach, North Island, New Zealand. Geological Quarterly, 65: 35, doi: 10.7306/gq.1604

\author{
Associate Editor: Anna Wysocka
}

The study focuses on sand grain properties in different parts of a beach-dune system built entirely of heavy mineral particles. These properties are related to: (1) resistance of particular minerals to weathering and abrasion, (2) hydraulic sorting in the swash zone, and (3) aeolian sorting during grain transport inland from the upper beach. The main waterlain and windlain sand properties depend on settling velocity which results from grain density (reflecting grain mineralogy), size, shape and roundness. The study was performed on the beach and dunes at Patea on the west coast of the North Island of New Zealand, which are comprised of heavy minerals assemblage containing a ferromagnetic (dominated by titanomagnetite) and non-ferromagnetic (mainly pyroxene and amphibole) fractions. The result demonstrates that three zones of different sand properties can be distinguished: (1) a lower swash zone dominated by non-ferromagnetic, larger and more angular particles which are carried back from the upper swash zone down the foreshore by the backwash; (2) an uppermost swash zone and beach with almost $100 \%$ of ferromagnetic, smaller and more rounded particles deposited at the back of the beach by the uprush, which during high tide and storms can reach the cliff toe, and can be reworked by wind; and (3) a climbing dune composed of a more poorly sorted mixture of non- and ferromagnetic particles. In terms of both mineralogy and grain size and shape, the dune sand is less uniform than the beach sand. Aeolian segregation resulted here in sand textural features opposite to those found in dune sands composed of light minerals. The results highlight the density-dependent variability of grain size and shape of beach-dune deposits consisting of only heavy minerals, and broaden our understanding of mechanisms of sedimentary processes which is particularly important when reconstructing older sedimentary successions.

Key words: titanomagnetite, black sand, beach-dune deposits, grain size distribution, grain shape and microtexture, aeolian sorting.

\section{INTRODUCTION}

Black sands contain high concentrations of heavy minerals, as ilmenite, rutile, zircon, monazite, garnet, sillimanite, magnetite, titanomagnetite and gold, and are referred to as "placer deposits" or simply "placers" (e.g., Rao, 1957; Gow, 1967; Komar and Wang, 1984; Li and Komar, 1992; Angusamy et al., 2005; Achayra et al., 2009; Badesab et al., 2012). Placers are found in various sedimentological environments and accumulate due to grain sorting by: (1) a moving water in streams and rivers; (2) a

\section{* Corresponding author, e-mail: dluzewski@uw.edu.pl}

Received: April 9, 2021; accepted: June 9, 2021; first published online: August 12, 2021 moving air during aeolian transport; (3) wave action in swash zone, and (4) during the interaction of one or more of these processes (e.g., Komar and Wang, 1984; Komar, 1989; Achayra et al., 2009; Pupienis et al., 2011; Badesab et al., 2012).

In the aeolian environment, the composition and texture of heavy mineral assemblages depend on the wind energy, source rock availability, climate, mineral durability to abrasion, and chemical weathering of unstable heavy minerals (Abuodha, 2003; Kasper-Zubillaga et al., 2008). On coasts, where aeolian and littoral processes interact, the properties of heavy minerals are additionally controlled by wave energy and velocity of longshore current (Acharya et al., 2009). Grain sorting of polymineral sand mixtures itself is controlled not only by differential entrainment, but also suspension, bedload transport, and kinetic sieving (Slingerland, 1984).

Many studies have undertaken experiments investigating the initiation of grain motion by a moving fluid but they were 
based on grains uniform in size and density (including here most of the wind tunnel and flume experiments; e.g., Bagnold, 1941; Mazzullo et al., 1986). Only Shields (1936) offered a non-dimensional analysis that allowed the determination of threshold values for entrainment of grains of different densities by flowing liquid, but not gases (Komar, 2007). There has also been research on sorting processes of grain mixtures containing either light minerals or light and heavy minerals (e.g., Trask and Hand, 1984; Li and Komar, 1987, 1992; Bartzke et al., 2018) and only a few studies focused on mixtures of only heavy minerals of different densities and sizes (e.g., Garzanti et al., 2008). These studies have shown that particles transport and deposition in a moving fluid largely depend on grain settling velocity which is related to grain size, density and shape (Hand, 1967; Komar and Reimers, 1978; Dietrich, 1982; Schuiling et al., 1985; Wu and Wang, 2006; Garzanti et al., 2008). However, mechanisms of heavy mineral grains sorting have been studied much more often in the case of flowing water (Slingerland and Smith, 1986; Komar, 1989; Cascalho et al., 2020) and impacts of different grain density, resulting from their different mineralogical composition, on sand grain sizes deposited by wind have not been fully investigated.

Beaches and dunes composed entirely of black sands, and particularly of heavy minerals with density between 3 and $\geq 5 \mathrm{~g} / \mathrm{cm}^{3}$, are uncommon all over the world. However, they provide opportunities for in-depth study of the impact of grain density on the sorting mechanism and textural properties of beachdune deposits. This issue is critical for correct interpretation of sedimentological mechanisms when investigating ancient sedimentary successions. The results of this study contribute to ongoing research by stressing that statistical parameters of grain size distributions, which are commonly used in interpretation of dynamics of different sedimentary processes, should consider the specific properties unique to heavy minerals.

Black sands of the Patea Beach, located at the West Coast of North Island of New Zealand, are a good example of placer deposits. The distinctive mineralogy of these sands has been known for some time (e.g., Cox, 1881) and because of the high concentration of titanomagnetite (Nicholson and Fyfe, 1958) they are locally known as "ironsand" (Thomson, 1917; Kear, $1965,1979)$. They are both of economic significance (Kear, 1965; Brathwaite et al., 2017, 2021) and a tourist attraction.

Little is known of the aeolian properties of sands composed of only heavy mineral grains, however, one might expect the threshold of motion of black sands to be higher compared with quartz sands - the density of pure titanomagnetite grains is $4.7-5.3 \mathrm{~g} / \mathrm{cm}^{3}$, almost twice that of quartz grains. Therefore, the study of the physical characteristics of these sediments can provide information that is useful for better understanding of their aerodynamic properties. In this study we analysed the textural parameters, as grain size, sorting, and skewness as well as grain shape, roundness and microtextures along the beach-dune system. We discuss the impact of grain density, size, and shape, resulting from their mineralogy, on grain entertainment and sorting by wind action.

\section{STUDY AREA}

The study site is located on the south coast of the Taranaki Peninsula on the west coast of the North Island of New Zealand (Fig. 1). The black beach and dune sands are derived from volcanic rocks of the central North Island (the Taupo Volcanic Zone) and the Egmont National Park volcanic complex, and carried to the coast by streams and rivers (Cockayne, 1909, 1911; Morgan and Gibson, 1927; Gow, 1968; Neall et al., 1986;
Edgett and Lancaster, 1993; Stewart et al., 1996). These deposits are transported north by the prevailing south-west swell that drives a south-to-north flow of beach, nearshore and inner shelf sand (Gorman et al., 2003; Brathwaite et al., 2014). The late Quaternary barriers of Awhitu and Aotea contain large amounts of this sand. Similar concentrations representing fossil beaches are known from the continental shelf (Summerhayes, 1967; Carter, 1980). These deposits have been locally diluted by erosion of non-volcanic rocks, but black sands are characteristic of almost $600 \mathrm{~km}$ of shoreline, from Whanganui north (Briggs et al., 2009). These beach deposits form by mechanical concentration of resistant heavy mineral particles of high specific gravity by the action of waves, currents, and winds (Bryan et al., 2007).

Along the south Taranaki coast most beach sand is derived from erosion of the lahar and debris avalanche deposits which flowed from the andesitic cone of Mount Taranaki (Neall et al., 1986; Turner et al., 2011; Zernack et al., 2012). The sands contain mainly titanomagnetite, augite, hornblende, and plagioclase feldspar (Morgan and Gibson, 1927; Gow, 1967, 1968; Briggs et al., 2009; Brathwaite et al., 2017). The coast is subject to tides (with tidal range of $\sim 2 \mathrm{~m}$ ) and high-energy, prevailing southwest waves produce a south to north littoral drift (Pickerill and Mitchel, 1979; Shepherd and Hesp, 2003). Waves from the south-west to west-southwest with heights of 1-3 m and periods $>12$ s occur $\sim 22 \%$ of the time in the centre of the Taranaki Bight (Mead, 2013). The prevailing winds are also from the south-west (Fig. 2). In response to wave events and resulted sand redistribution the elevation of Patea beach fluctuates from 0.8 to $2.0 \mathrm{~m}$ and the beach face moves seaward and landward in the range of $\sim 20 \mathrm{~m}$ (Hume et al., 2012). During the study survey the beach was wide and characterised by low gradient and flat morphology. The width of the Patea beach is important for the intensity of aeolian sand transport as it determines available fetch which is critical for the amount of sand delivered to the dunes (Bauer and Davidson-Arnott, 2002; Houser, 2009; Davidson-Arnott, 2010). The fetch is limited during high tide or storms when a significant part of the beach is wet or moist due to groundwater drainage (Bauer and Davidson-Arnott, 2002).

The study site is characterised by an average of $882 \mathrm{~mm} / \mathrm{y}$ of rainfall, 115 wet-days per year, $2043 \mathrm{~h} / \mathrm{y}$ of sunshine (based on 23-years of data from Whanganui Spriggens Park weather station, www.timeanddate.com). The mean annual temperature is $14.0^{\circ} \mathrm{C}$, the highest annual temperature is $32.3^{\circ} \mathrm{C}$ and the lowest annual temperatures is $-2.3^{\circ} \mathrm{C}$. Annual mean wind speed equals to $5.0 \mathrm{~m} / \mathrm{s}$ and gales, i.e., the wind with speed equal to or exceeding $17.5 \mathrm{~m} / \mathrm{s}$, occur on average during 5 days per year.

The frequent occurrence of dunes on the West Coast of the North Island indicate that the high-energy conditions resulting from the intersection of the New Zealand land mass with the westerly wind belt (locally known as the 'roaring forties') are sufficient to transport titanomagnetite-rich sands in a range of onshore wind conditions. The onshore sand drift potential (DP) (Fryberger and Dean, 1979) for the Spriggens Park dataset is high (DP = 1855) for this coast (Muckersie, 1989). Additionally, the beaches between Taranaki and Wanganui River are backed by a steep cliff, $\sim 30 \mathrm{~m}$ high, formed in Pleistocene marine terraces (Shepherd and Hesp, 2003) built of Pliocene Wanganui Series mudstones, sandstones, shell beds, limestones and conglomerates (McGlone et al., 1984; Pillans, 1990). These cliffs are responsible for rapid localised acceleration of wind flow, which must locally enhance the drift potential value. Aeolian bedforms present at the coast are dominated by climbing and cliff-top dunes and transgressive and parabolic 

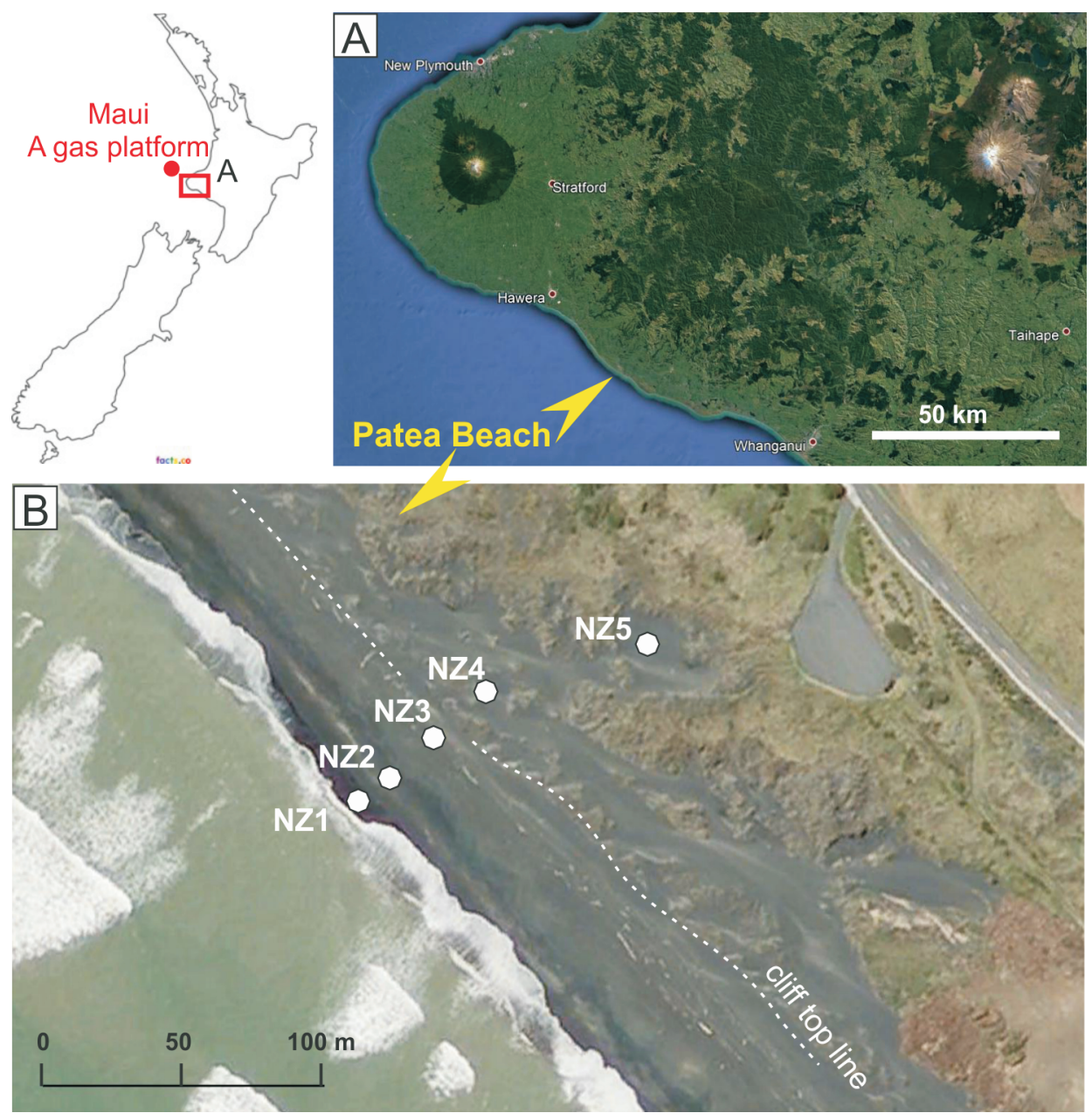

Fig. 1A - study site; B - location of sand samples (www.googlemap.com, 13 February 2007)

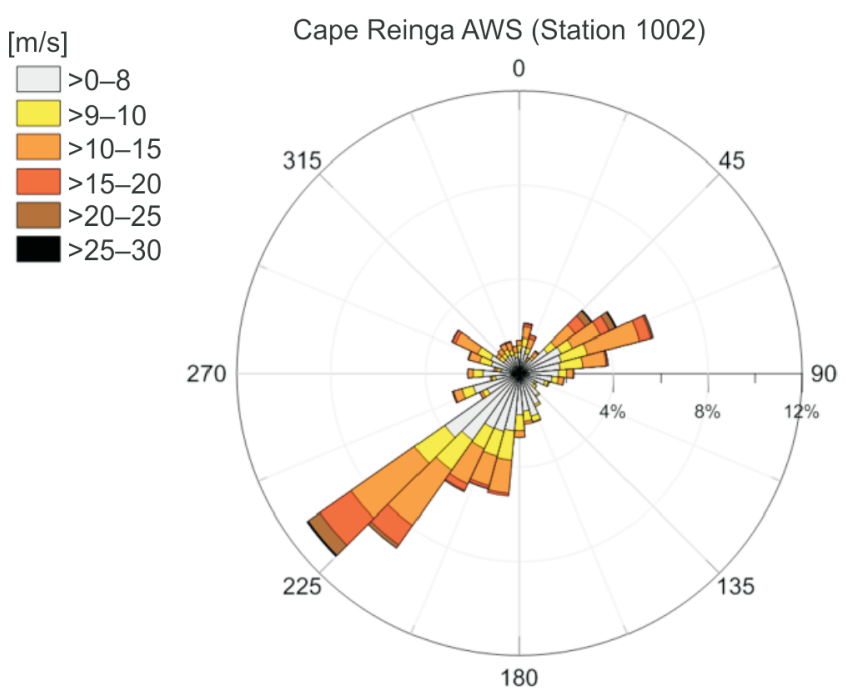

Fig. 2. Wind rose derived from observations (2001-2011) at the Maui $A$ oil and gas platform (Fig. 1), $101 \mathrm{~km}$ north-west of Patea

Data provided by National Institute of Water and Atmospheric Research - Taihoro Nukurangi dune fields. Only some of them, as at Patea, are still active. The others, which were initiated at lower sea-levels, when a cliffed coast was located $\sim 6 \mathrm{~km}$ south of the present coastline and which during the postglacial marine transgression migrated landward, are entirely relict (Shepherd and Hesp, 2003).

\section{MATERIAL AND METHODS}

The surface sand samples, each weighing $150 \mathrm{~g}$, were collected at Patea Beach on February 16th, 2018, just after high tide. Prior to sampling, over a period of 7 days, the wind was blowing mainly alongshore from north-west and west with 6-hour average wind speeds between $3.06 \mathrm{~m} / \mathrm{s}$ and $8.61 \mathrm{~m} / \mathrm{s}$ (www.timeanddate.com). Sediment samples were collected from five sites along a shore normal transect: NZ1 - lower part of the swash zone, NZ2 - uppermost swash zone, NZ3 - upper beach with small shadow dunes formed behind Ficinnia spiralis (pīngao), NZ4 - lower part of the climbing dune, and NZ5 - upper part of climbing dune (Fig. 1). Each sample was analysed for grain size distribution, mineral composition, grain shape, roundness and grain microtexture.

\section{MINERALOGICAL COMPOSITION}

The mineralogy of raw and sieved subsamples was determined. Preliminary identification was achieved under binocular 
microscope and in thin sections under transmitted, polarized light, and then complemented by powder X-ray diffraction and electron-dispersive spectroscopy (EDS) analyses.

The X-ray diffraction analysis examined the mineral composition of raw samples. They were analysed with an ARL Thermo X'tra diffractometer at the Institute of Geology, Adam Mickiewicz University in Poznań, Poland. The diffractometer operated at $40 \mathrm{kV}$ and $30 \mathrm{~mA}$, with a $2 \mathrm{~mm}$ divergence slit, a $4 \mathrm{~mm}$ antiscatter slit, and receiving slit of $0.5 \mathrm{~mm}$. The disoriented powder aggregates were analysed from 3 to $70^{\circ} 2$ theta.

The EDS analysis enabled us to measure the chemical composition of mineral grains and helped in mineral identification. The elemental analyses of carbon coated samples were performed on a Sigma VP Ziess scanning electron microscope (SEM) at the Nano-Fun Laboratory at the Faculty of Geology, University of Warsaw, Poland. Standardless energy-dispersive X-ray spectroscopy analysis was carried out using a BRUKER Xflash $6 \mid 10$ EDS detector. For each raw sand sample 100 grains were analysed.

\section{GRAIN SIZE ANALYSIS}

Grain size distributions were determined by dry sieving to quarter phi intervals ranging from 0 phi $(1000 \mathrm{~mm})$ to 4 phi $(63 \mathrm{~mm})$. The sieve data were analysed using Gradistat v. 8 (Blott and Pye, 2001). Grain size parameters presented in the paper follow Folk and Ward (1957) graphical method: mean grain diameter $(\mathrm{Mz})$, standard deviation (sorting $-\sigma_{\mathrm{l}}$ ) and skewness $\left(\mathrm{Sk}_{\mathrm{l}}\right)$. It was important to determine the weight percentage of grains in each sand size range (defined to $1 / 4 \mathrm{phi}$ ) as there is a significant difference in grain density between titanomagnetite, and other minerals in the samples. As titanomagnetite is ferromagnetic, this mineral was separated from the sub-samples obtained in each sieve using a hand magnet, thus providing the weight percentage of ferromagnetic and non-ferromagnetic fractions in each grain size class.

\section{GRAIN SHAPE AND ROUNDNESS}

The shape of grains in the raw (un-sieved) samples separated into ferromagnetic and non-ferromagnetic subsamples was determined using the Morphologi G3SE (Szmańda et al., 2018) at the Sedimentological Laboratory, Institute of Geography, Pedagogical University of Cracow, Poland. The Morphologi G3 allows for automated static image analysis which provides a description of the morphological properties of grains, as: (1) grain size expressed by grain diameter (and/or major axis), (2) grain elongation (1 minus the ratio of grain width to length), (3) circularity (the ratio of the circumference of a circle equal to the object's projected area multiplied by $4 \pi$ to the perimeter of the grain), (4) convexity (the perimeter of the convex hull perimeter of the particle divided by its real perimeter), and (5) solidity (the real grain area divided by the area enclosed by the convex hull; following the Morphologi G3 user Manual). More than 1000 grains were analysed in each sub-sample. All parameters are represented as the averages for each size class, provided it contained $>30$ grains, otherwise, the results of analysis were not taken into account.

Grain roundness was determined on the basis of SEM photos separately for ferromagnetic and non-ferromagnetic grains. Five classes of roundness were distinguished: angular (A); subangular (SA); subrounded (SR); rounded (R); and crushed grains (C) (Reichelt, 1961). For statistical reliability, 100 grains were counted in each sample.

\section{GRAIN MICROTEXTURE}

Heavy mineral grains were fixed onto standard SEM stubs using double-sided sticky tape. The microtexture of heavy mineral grains was analysed using a scanning electron microscope (SEM) using the microtexture classification proposed by Mahaney (2002) and extended by microforms included in the work of Velbel (2007). Grains were analysed in two stages. The first stage examined the degree of grain surface differentiation (high, middle or low relief), the nature of the edge (rounded or sharp edges), and the presence of fresh surfaces. The second stage was associated with scanning the surface of grains and recording microtextures on their surfaces.

\section{RESULTS}

\section{SAND MINERALOGY}

The XRD results show that the black sand from Patea Beach, beach and dune environments, is composed of magnetite/titanomagnetite, clinopyroxene (augite and diopside), with a smaller quantity of amphibole (mainly hornblende) grains (Fig. 3). Titanomagnetite grains are slightly oxidized to hematite. Results of XRD analysis coincide with the results of EDS analysis. The analysis of chemical composition shows that the magnetite grains have an admixture of titan (up to $21.2 \%$ of $\mathrm{TiO}_{2}$ ) and they may be classified as titanomagnetite (Table 1). On the basis of SEM-EDS analysis it was possible to determine the percentage of grains of the ferromagnetic fraction, including pure titanomagnetite grains and pyroxene and amphibole grains with titanomagnetite intergrowths, and non-ferromagnetic fractions (amphiboles, pyroxenes and others; Table 1).

Under the binocular microscope, pyroxene grains were short prismatic, light green to green, whereas amphibole grains are long prismatic, dark green and brown (Fig. 4). Titanomagnetite grains are distinguished by strong metallic luster and were usually well rounded, but some grains of original octahedral habit were observed (Fig. 5A). Their magnetic property manifested itself by grain attraction that led to formation of grain chains and aggregates (Fig. 5B-D). The chains resulting from magnetic interactions must have significant implications for aeolian processes. Many of the grains contained tiny intergrowths of opaque minerals, mostly titanomagnetite (Fig. 5E).

Under the polarizing microscope, the pyroxene grains are green with poorly visible pleochroism and a large extinction angle. The amphiboles exhibited strong pleochroism from dark green to dark brown and had a low angle of extinction.

The different minerals have significantly different densities. In the case of titanomagnetite it is $\sim 4.7-5.3 \mathrm{~g} / \mathrm{cm}^{3}$. Pyroxene and amphibole have a density of $3.2-3.4 \mathrm{~g} / \mathrm{cm}^{3}$ (Mange and Maurer, 1992).

The sand mineralogy significantly varied along the beachdune transect and depends on the size fraction. Sand in the lower part of the swash zone (NZ1) in all size fractions was dominated by grains of pyroxene and subordinate amphibole, which constituted in total $80 \mathrm{wt}$ \% (Fig. 6). The remaining grains fall into the ferromagnetic fraction, but they were not pure ferromagnetic grains, but mostly pyroxene or amphibole with intergrowths of titanomagnetite (Figs. 4A and 5E).

Sand from the uppermost swash zone (NZ2) and the upper beach (NZ3) are 97 wt.\% of titanomagnetite grains (Figs. 4B, C, $5 \mathrm{~B}, \mathrm{~F}$ and 6$)$. Other grains were pyroxene and amphibole with intergrowths of titanomagnetite. 

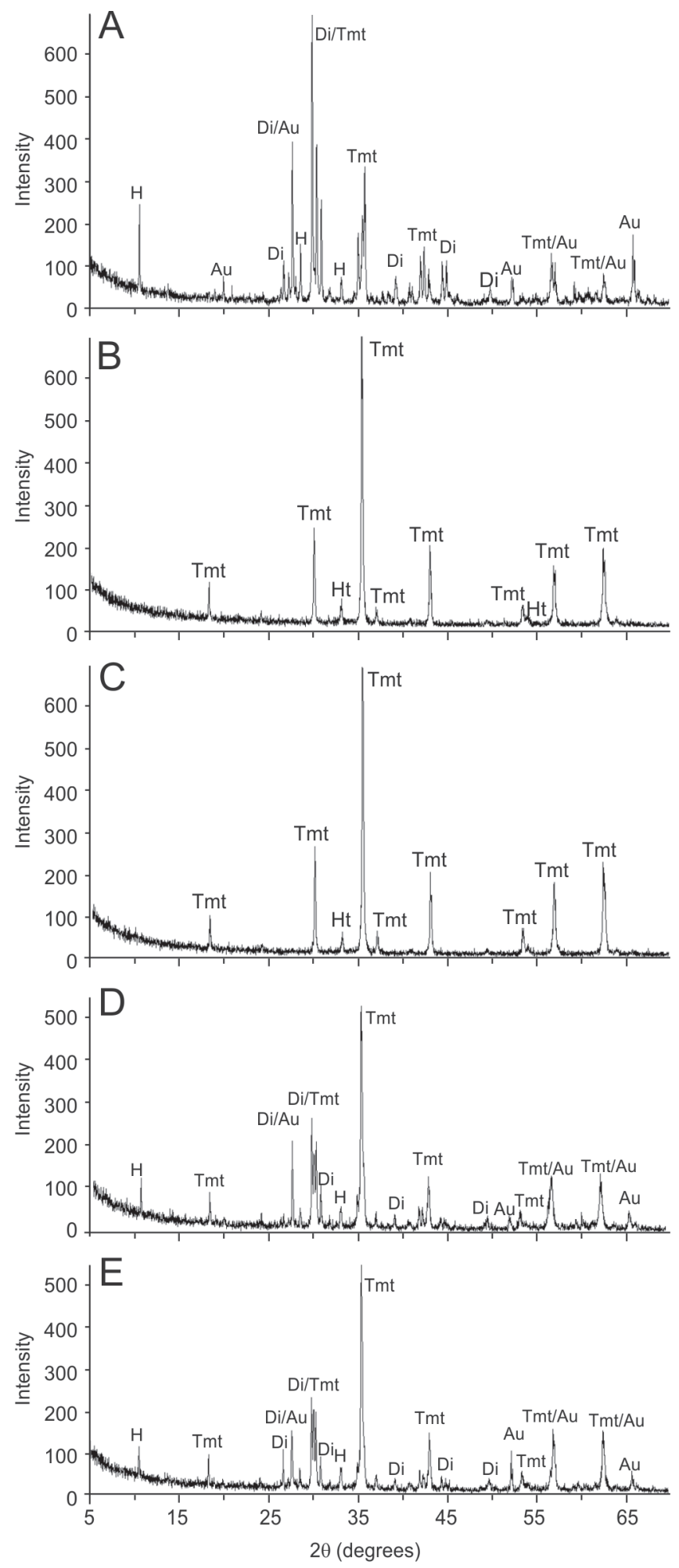

Fig. 3. XRD results of raw sand samples

A - lower part of the swash zone (NZ1); B - the uppermost swash zone (NZ2); C - upper beach (NZ3); D - lower part of climbing dunes (NZ4); E - upper part of climbing dunes (NZ5); Di - diopside, Au augite, $\mathrm{H}$ - hornblende, $\mathrm{Ht}$ - hematite, $\mathrm{Tmt}$ - titanomagnetite
The dune sand samples contained the most diverse assemblage of heavy minerals (NZ4 and NZ5; Figs. 4D, E, 5B and 6). Ferromagnetic grains constituted about half of the weight of samples, but again a significant percentage of each sample was comprised of pyroxene and amphibole, with titanomagnetite intergrowths.

\section{GRAIN SIZE DISTRIBUTIONS}

Grain size distributions of the samples show a strong relationship with mineralogical composition (Fig. 7). The lower swash zone sand (Fig. 7A), comprising mainly non-ferromagnetic grains, has a mean grain size similar to the sand deposited within the lower and upper part of the climbing dunes, which itself is comprised of a mixture of ferromagnetic and non-ferromagnetic grains (Fig. 7D, E). In contrast, upper swash zone and upper beach samples are predominantly comprised of much smaller ferromagnetic grains, in the modal class of 150-180 $\mu \mathrm{m}$ (Fig. 7B, C). Ferromagnetic grain size within samples from the climbing dunes are much smaller than the non-ferromagnetic grains (Fig. 8). The exception is the lower swash zone where the mean ferromagnetic grains size is similar to that of non-ferromagnetic mean grain size in the modal class 212-250 $\mu \mathrm{m}$ (Fig. 7A). These are not pure ferromagnetic grains but pyroxene and amphibole with magnetite and titanomagnetite intergrowths.

Raw sand samples from the swash zone and upper beach

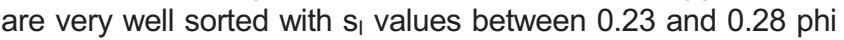
(Fig. 7A-C). Samples from the climbing dunes are less sorted $\left(\sigma_{l}=0.44-0.49\right.$; Fig. 7D, E). Ferromagnetic grains are much better sorted within the upper swash zone and upper beach deposits, i.e., within the zone of wave action, and much worse in samples from climbing dunes subject to aeolian processes (Fig. 8). Non-ferromagnetic grains are better sorted in both the swash zone and lower part of the climbing dunes, compared to the upper part of the climbing dunes. Regardless of the analysed fraction, climbing dune sand is less sorted than beach and swash zone sand which is the reverse of usual patterns for sand deposited by aeolian processes (see Discussion). The grain size distributions of sand collected from the uppermost swash zone, upper beach and lower part of the climbing dunes are positively skewed whereas the distributions of sand collected from the lower part of the swash zone and upper part of climbing dune are symmetrical (Fig. 7).

\section{GRAIN SHAPE AND ROUNDNESS}

Grain shape significantly differs between ferromagnetic and non-ferromagnetic mineral assemblages. However, the small number (<2.5 wt.\%) of non-ferromagnetic grains (pyroxene and amphibole) in sand samples from the upper swash zone and beach sands precludes analysis of their shape.

In most samples titanomagnetite grains are characterized by higher circularity than pyroxene and amphibole grains (Fig. 9). Regarding shape, only ferromagnetic grains from the lower part of the swash zone (NZ1) differ from ferromagnetic grains found in other samples (Fig. 9). This is because they mainly comprise large grains of pyroxene and amphibole with titanomagnetite intergrowths. For the same reason their circularity decreases with grain diameter, as with non-ferromagnetic grains (Fig. 9). Non-ferromagnetic grains are generally more elongated than titanomagnetite grains. Additionally, the larger the non-ferromagnetic grains, the more they are elongated (Fig. 9B). Convexity and solidity are higher for titanomagnetite grains (Fig. 9), indicating that ferromagnetic grains are 
Summary statistics showing the composition of beach and dune black sand at Patea

\begin{tabular}{|c|c|c|c|c|c|c|c|c|c|c|c|c|c|}
\hline \multicolumn{9}{|c|}{ Content (\%) of: } & \multicolumn{5}{|c|}{$\begin{array}{c}\text { Percentage of grains in samples } \\
(n=100 \text { grains per sample })\end{array}$} \\
\hline & $\mathrm{TiO}_{2}$ & $\mathrm{FeO}$ & $\mathrm{MgO}$ & $\mathrm{Al}_{2} \mathrm{O}_{3}$ & $\mathrm{MnO}$ & $\mathrm{SiO}_{2}$ & $\mathrm{CaO}$ & $\mathrm{Na}_{2} \mathrm{O}$ & NZ1 & $\mathrm{NZ2}$ & NZ3 & NZ4 & NZ5 \\
\hline \multicolumn{9}{|c|}{ Titanomagnetite $(n=294)$} & \multirow[t]{4}{*}{4} & \multirow[t]{4}{*}{85} & \multirow[t]{4}{*}{86} & \multirow[t]{4}{*}{51} & \multirow[t]{4}{*}{68} \\
\hline Min & 2.94 & 71.34 & 0.67 & 0.87 & 0.00 & & & & & & & & \\
\hline Max & 21.20 & 88.23 & 7.04 & 8.87 & 1.82 & & & & & & & & \\
\hline Average & 9.07 & 79.43 & 3.77 & 4.48 & 1.15 & & & & & & & & \\
\hline \multicolumn{9}{|c|}{ Pyroxene $(n=109)$} & \multirow[t]{4}{*}{64} & \multirow[t]{4}{*}{0} & \multirow[t]{4}{*}{0} & \multirow[t]{4}{*}{33} & \multirow[t]{4}{*}{12} \\
\hline Min & 0.00 & 5.27 & 11.71 & 1.85 & 0.00 & 39.93 & 14.24 & 0.00 & & & & & \\
\hline Max & 1.50 & 14.58 & 20.52 & 9.78 & 1.03 & 49.42 & 30.88 & 2.06 & & & & & \\
\hline Average & 0.54 & 8.65 & 16.25 & 4.27 & 0.22 & 45.76 & 23.35 & 0.91 & & & & & \\
\hline \multicolumn{9}{|c|}{ Amphibole $(n=20)$} & \multirow[t]{4}{*}{9} & \multirow[t]{4}{*}{2} & \multirow[t]{4}{*}{0} & \multirow[t]{4}{*}{6} & \multirow[t]{4}{*}{3} \\
\hline Min & 0.00 & 1.04 & 0.44 & 15.22 & 0.00 & 45.00 & 0.88 & 2.59 & & & & & \\
\hline Max & 1.08 & 11.61 & 6.13 & 31.09 & 0.08 & 65.38 & 15.31 & 8.72 & & & & & \\
\hline Average & 0.45 & 4.35 & 2.13 & 21.34 & 0.00 & 56.73 & 5.30 & 6.46 & & & & & \\
\hline \multicolumn{9}{|c|}{ Pyroxene or amphibole grains with titanomagnetite intergrowths $(n=40)$} & 12 & 8 & 5 & 6 & 9 \\
\hline \multicolumn{9}{|c|}{ Other mineral grains $(n=37)$} & 11 & 5 & 9 & 4 & 8 \\
\hline
\end{tabular}

Left and right parts of table show the chemical composition of minerals and percentage of grains in samples, respectively. The chemical composition was determined using the EDS method. Site of sand samples: NZ1 - lower swash zone, NZ2 - upper swash zone, NZ3 - upper beach, NZ4 - lower part of climbing dunes, NZ5 - upper part of climbing dunes.

smoother than non-ferromagnetic grains. Grain size does not affect the value of these two parameters (Fig. 9).

Likewise, the roundness of grains differs between particular zones of the beach-dune system. In the lower part of the swash zone subangular and angular grains dominate $(>70 \%)$, but grain angularity is much lower in other zones - it varies between $10 \%$ in the uppermost swash zone and upper beach, and is $\sim 30 \%$ in the climbing dune sand (Fig. 10). With the exception of the lower swash zone, the ferromagnetic mineral assemblage is dominated by sub-rounded and rounded grains in different proportions (Fig. 10B-E).

Broken non-ferromagnetic grains are present only in a small amount, mostly in dune deposits, i.e., within particles transported by wind (Fig. 10D, E). Non-ferromagnetic sub-angular, sub-rounded and rounded grains occur in various proportions, with sub-angular grains dominating in the lower part of the swash zone and the upper part of the climbing dunes (Fig. 10A, $E)$, and rounded grains dominating in the lower part of the climbing dunes (Fig. 10D). The proportion of angular grains is highest in the lower swash zone $(13.6 \%)$ and decreases in the upper dune sand, which is enriched in broken grains (9\%).

\section{GRAIN MICROTEXTURES}

The surface of pyroxene and amphibole grains from the swash zone and upper beach (NZ1-NZ3) shows mechanical rounding in the swash zone (Fig. 11A-E). These rounding features include smooth surfaces, varied lenticular etch pits parallel to each other (crystallographically controlled dissolution voids) and randomly distributed and dendiculated margins (Fig. 11B, C). On the most convex fragments of grains, etch pits are overprinted by dissolution surfaces. A number of microtextures that were the effect of mechanical destruction of the grain surface were also observed. Among them, small $(<10 \mu \mathrm{m})$ and large $(>10 \mu \mathrm{m})$ conchoidal fractures and fracture faces dominate. Most of these microtextures have fresh surfaces and sharp edges (Fig. 11B, C). However, individual small scale etch pits also occur on the surface of fracture faces (also Fig. 11A). The effects of aeolian abrasion on the surface of py- roxenes and amphiboles found in the climbing dune sand (NZ4 and NZ5) are much less pronounced than effects of marine abrasion in the grains in the lower part of the swash zone (Fig. 11D-E).

On the surface of titanomagnetite grains, both dissolution effects and mechanical abrasion can be observed (Fig. 11D-O). Dissolution is marked in the form of: (1) a smooth surface within micro depressions present on grain surfaces; (2) irregular surfaces, observed mainly on the most convex parts of individual grains (Fig. 11G, H); and (3) skeletal titanomagnetite, which consist only of ilmenite lamellae, oriented parallel to the octahedral [111] plane (Fig. 110). However, in the same sample, both unchanged idiomorphic (octahedral) grains and grains with traces of abrasion and dissolution at the edges may coexist (Fig. 111, O - from the same sample). Mechanical abrasion is expressed by common conchoidal fractures occurring both on small $(<10 \mu \mathrm{m})$ and large $(>10 \mu \mathrm{m})$ scales, as well as by linear and parallel steps, arc-shaped steps and crescentic gouges, with fresh surfaces and sharp edges (Fig. 11F, K-N). There are also some grains with sharp edges and fresh conchoidal fractures, present on the surface (Fig. 11F, K-N), and some with conchoidal fractures that are overprinted by dissolution (Fig. 11L). The most convex parts of titanomagnetite grains from the climbing dune are characterized by smooth surfaces and fewer dissolution microtextures (Fig. 11M).

\section{DISCUSSION}

The Patea black sands provide an excellent example of contemporary heavy mineral deposits within a beach-dune system, which exhibits textural features that are unique for a beach-dune environment. It is manifested by the mineral composition of sand which includes two heavy mineral assemblages (pyroxene plus amphibole, and titanomagnetite), which differ in mineral density by as much as nearly $2 \mathrm{~g} / \mathrm{cm}^{3}$.

Our studies show that along a beach-dune transect, where aeolian transport takes place, grain size increases, whereas sorting decreases. Moreover, during aeolian transport up the 

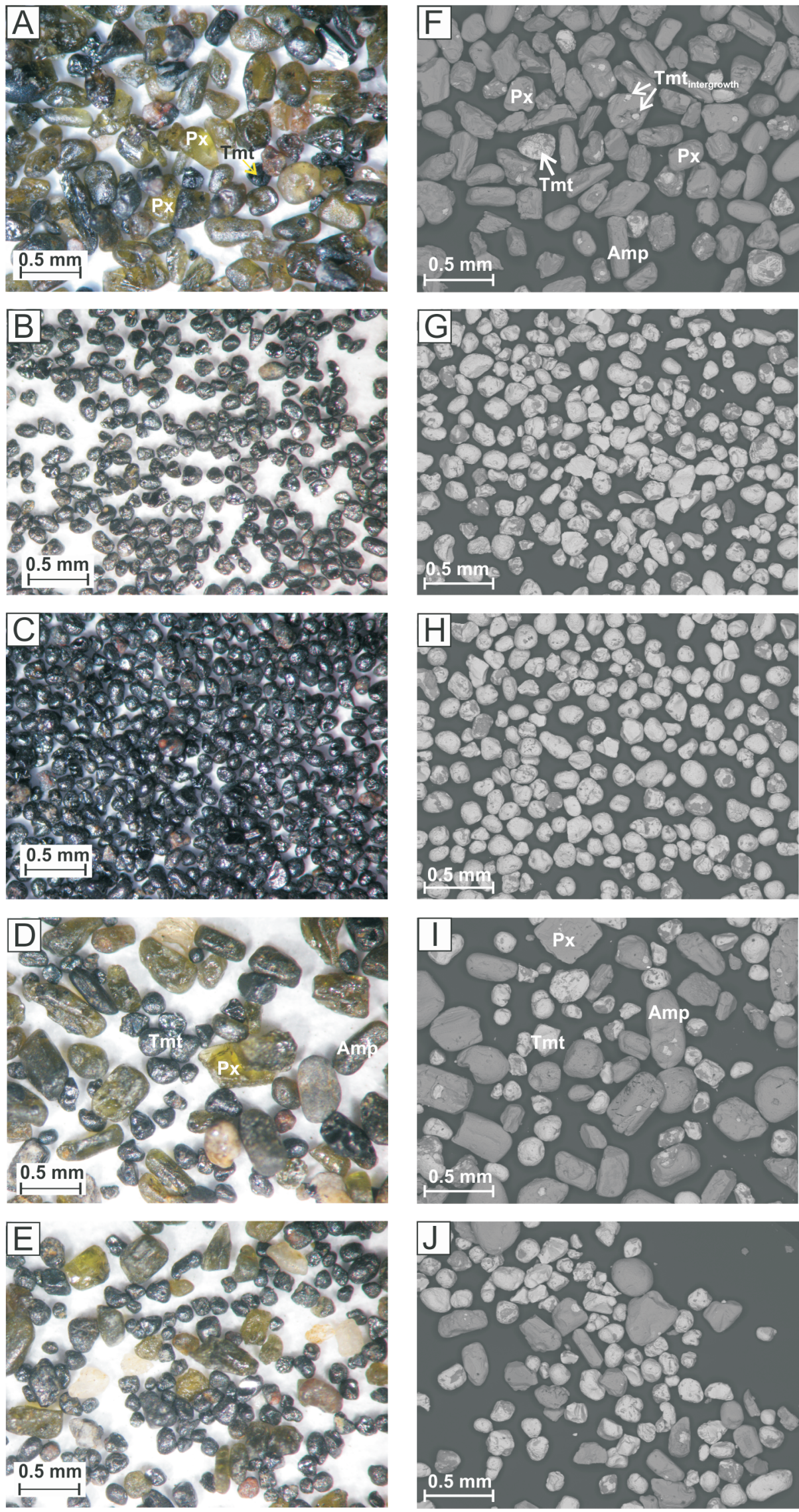

Fig. 4. Mineralogical composition of sand samples: binocular microscope (left column) and SEM (right column) photographs

A, F - lower part of the swash zone; B, G - the uppermost swash zone; C, H - upper beach; D, I- lower part of climbing dunes; E, J - upper part of climbing dunes. Differences in grain size in relation to different minerals are clearly evident. All photos are taken at the same magnification. The grains show the following features: Tmt - titanomagnetite (strong metallic lustre, usually well rounded), Px - pyroxene (usually light green to green, short prismatic, perfect to distinct cleavage at approximately right angles), Amp - amphibole (dark green and brown, long prismatic, perfect to distinct cleavage at an angle of $\sim 120^{\circ}$ ), Tmtintergrowth - intergrowths of titanomagnetite in Px or Amp 

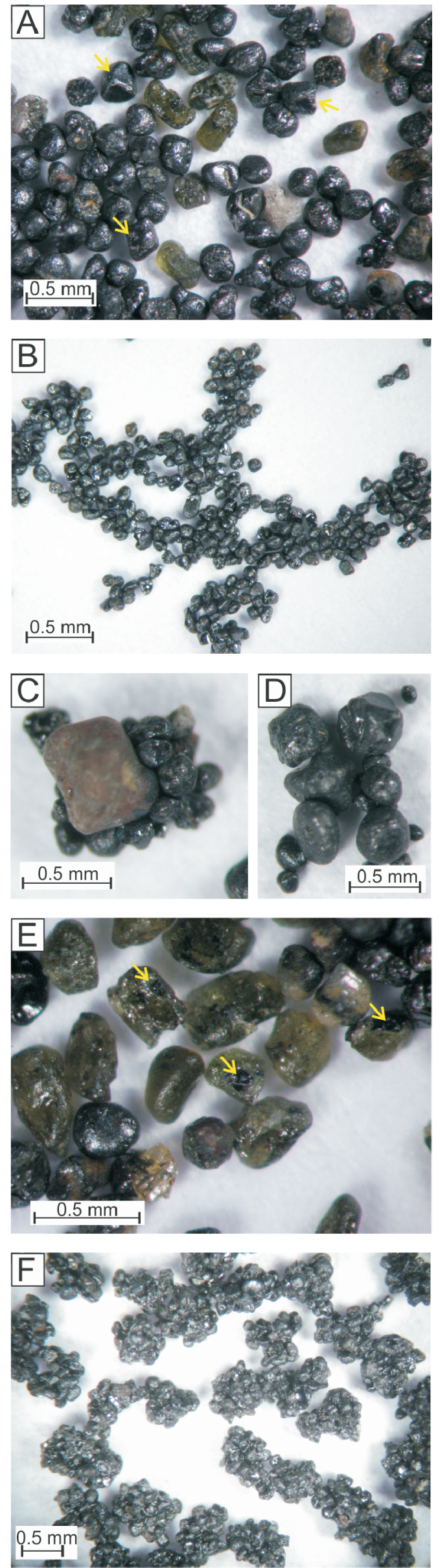

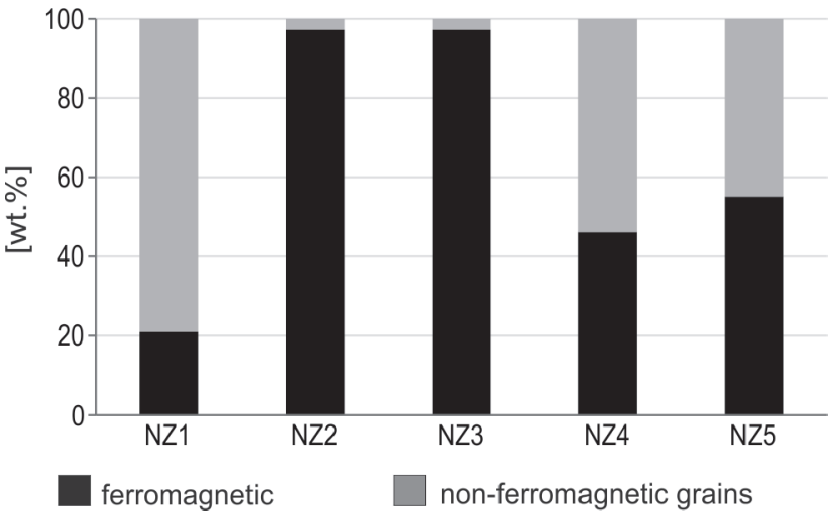

Fig. 6. Weight percentage of ferromagnetic (titanomagnetite) and non-ferromagnetic (mainly pyroxene and amphibole) fractions in raw sand samples collected along the beach-dune transect

Sample locations: NZ1 - lower part of the swash zone, NZ2 - the uppermost swash zone, NZ3 - upper beach, NZ4 - lower part of climbing dune, NZ5 - upper part of climbing dune

slope of the climbing dune, i.e., during wind-flow acceleration, grain size decreases. In the case of dunes built of quartz sand, these trends are opposite (Dłużewski, 2013). Additionally, primary crystallographic morphology of the heavy mineral grains are responsible for different grain shapes and contribute to differing propensities to abrasion during transport. As a result, sand in the climbing dune contains very well-rounded and highly spherical titanomagnetite grains which are accompanied by elongated and less rounded pyroxenes and amphibole grains.

\section{SORTING OF SAND GRAINS IN THE BEACH-DUNE SYSTEM}

Hydraulic sorting of mineral grains in the swash zone has usually been considered to result in the separation of light and heavy minerals due to differences in their densities, size and shape. Despite the varied mechanisms responsible for this sorting (suspension sorting, entrainment sorting, transport sorting, and shear sorting; Slingerland and Smith, 1986; Komar, 1989), the result is usually the accumulation of heavy minerals in the upper part of the swash zone with maximum concentration recorded at the upper limit of wave run up (Cascalho and Taborda, 2006). The density contrast of grains composing the swash zone at Patea beach is similar (and greater, depending on the mineral) to that between quartz grains $\left(2.63 \mathrm{~g} / \mathrm{cm}^{3}\right)$ and the different heavy minerals commonly known from beach placers, such as non-opaque minerals (i.e., garnet, zircon, rutile, tourmaline, epidote - with average density of $3.4 \mathrm{~g} / \mathrm{cm}^{3}$ ) and opaque minerals $\left(\sim 4.8 \mathrm{~g} / \mathrm{cm}^{3}\right)$. Thus, at the Patea Beach, sorting process results in accumulation of titanomagnetite grains (as grains of higher density) in the uppermost swash zone and dominance of less dense amphibole and pyroxene grains in the

\section{Fig. 5. Some features of sand samples/grains}

A - well-rounded and octahedral ferromagnetic grains (lower part of climbing dune, size class 212-250 $\mu \mathrm{m}$ ); B, C, D - chains and aggregates formed due to magnetic attraction of grains found in sand samples collected from the upper beach and climbing dunes (size classes: $150-180 \mu \mathrm{m}$ and $425-500 \mu \mathrm{m}$, respectively); E - intergrowths of titanomagnetite in pyroxene grains (lower swash zone, size class $212-250 \mu \mathrm{m}) ; \mathbf{F}$ - aggregates of ferromagnetic grains bound with salt (upper swash zone, size class $500-600 \mu \mathrm{m}$ ) 

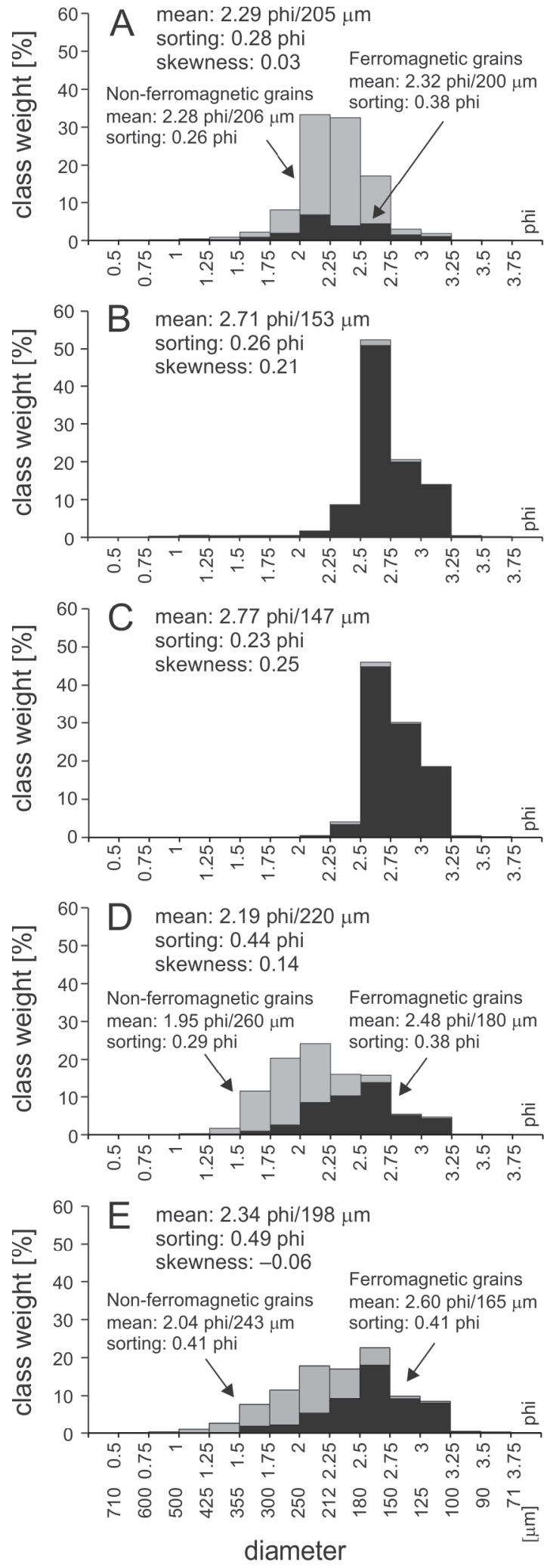

ferromagnetic $\square$ non-ferromagnetic grains

Fig. 7. Grain size distributions of sand

A - lower part of the swash zone (NZ1); B - the uppermost swash zone (NZ2); C - upper beach (NZ3); D - lower part of climbing dunes (NZ4); E - upper part of climbing dunes (NZ5); each box represents the total weight of ferromagnetic and non-ferromagnetic grains in each size class.

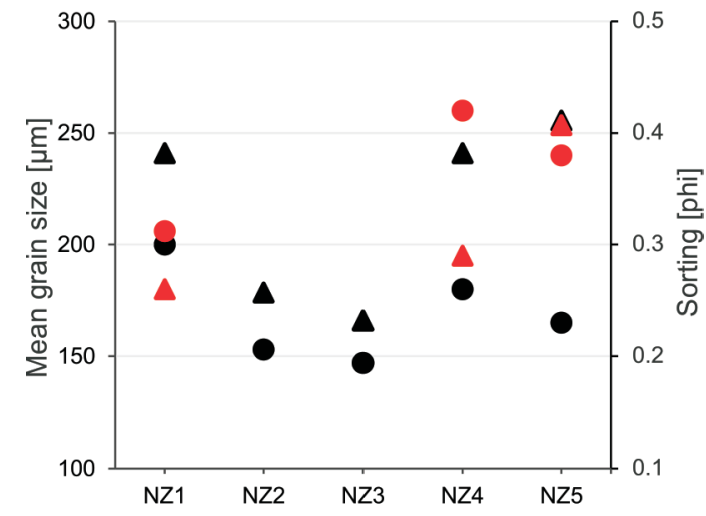

Ferromagnetic grains

- mean grain size

$\Delta$ sorting

Non-ferromagnetic grains

mean grain size

$\Delta$ sorting

Fig. 8. Mean grain size and sorting of ferromagnetic and non-ferromagnetic grains

Sample locations (NZ1-NZ5) as in Figure 7

remaining part of the swash zone (Fig. 6). Although, significant differences between the morphology of the swash zone profiles and the wave climate may occur in different seasons, grain size analysis does not usually record these changes and, as shown by Hartmann (1991), grain populations within the swash zone reflect the sum of long-term processes.

The threshold of grain movement within the swash zone is not only a function of grain size and wave parameters but also grain shape. This threshold will be exceeded for given wave conditions, grain size and densities for those grains that exhibit the largest drag, i.e., the grains of low sphericity. However this parameter has been largely neglected due to difficulties in its analysis (Poche and Goodel, 1975). Since the threshold of grain movement is a function of wave energy, its correlation with grain-shape parameters should indicate selective transport of grains of similar shapes. Where grains have the same size and shape, grains with the lowest settling velocities are moved preferentially over more spherical grains due to their larger coefficients of drag (Bagnold, 1966; Poche and Goodel, 1975).

At Patea, the maximum range of the swash zone moves landward and seaward during the tidal cycle and can reach the cliff toe during storm surges. As a consequence, the upper part of the high tide swash zone is exposed during low tide and, after drying, is subject to aeolian processes. The process of enrichment of the upper beach in the ferromagnetic grains is probably accompanied by deflation of pyroxene and amphibole grains. Thus, as in other regions, placer deposits in the uppermost beach appear to have accumulated by a combination of wave action, perhaps mostly by storm waves, and wind sorting (Schmidt and Asad, 1962).

Our results on grain sorting within a beach-dune system composed of heavy mineral grains raise several questions about wind sorting. First, what is the actual threshold wind velocity for particular sand grains composing the beach and dunes at Patea? According to Bagnold (1941), the potential for particles to be eroded and transported by wind is a function of average grain size, density and shear wind speed. Thus, the 

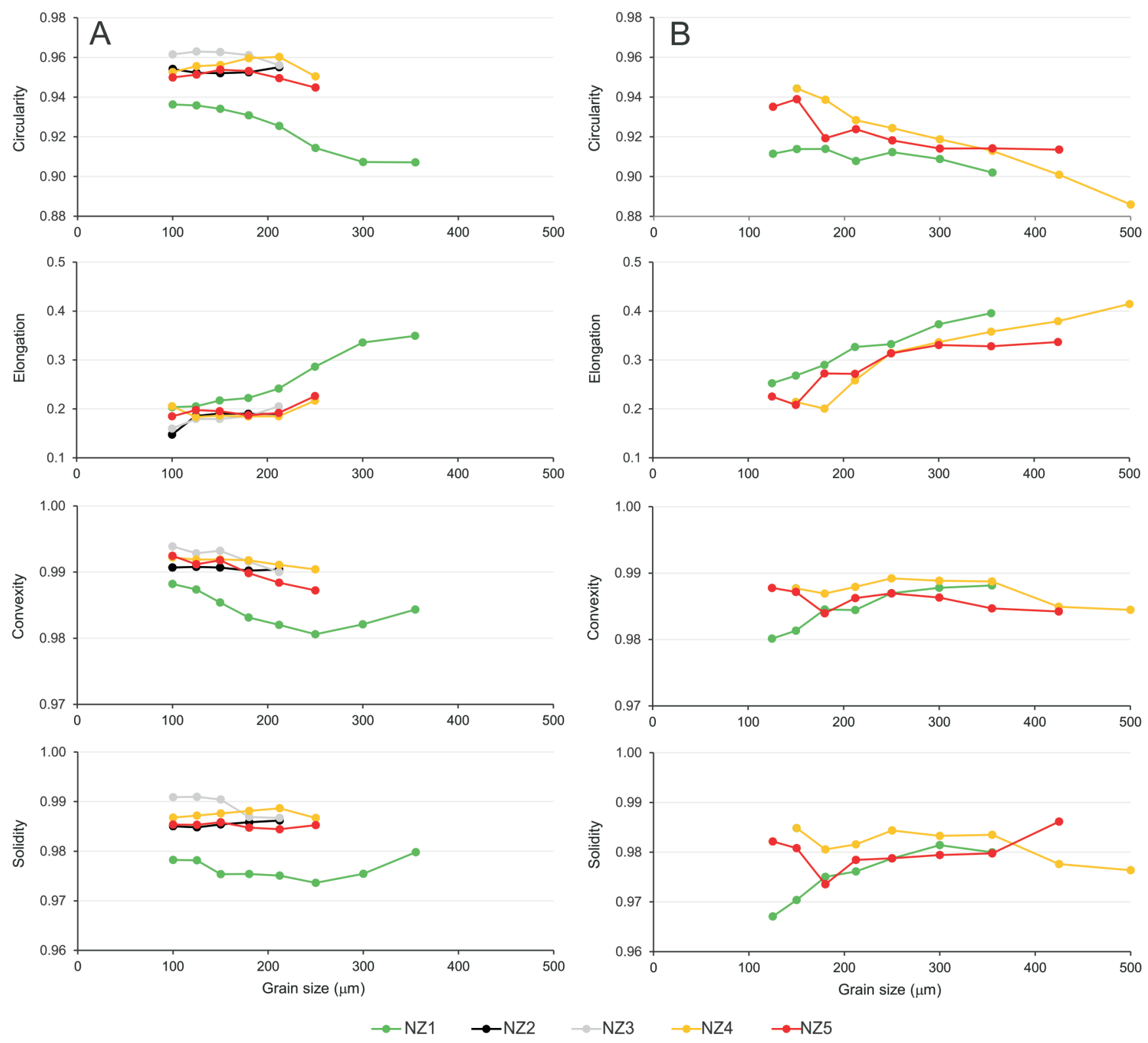

$\rightarrow \mathrm{NZ3} \rightarrow \mathrm{NZ4} \rightarrow \mathrm{NZ5}$

Fig. 9. Variation in grain circularity, elongation, convexity and solidity

A - ferromagnetic; B - non-ferromagnetic fractions in relation to grain size; sample location (NZ1-NZ5) as in Figure 5

maximum critical threshold wind velocity necessary for the initiation of grain motion by wind is reflected by wind speed needed to move the coarsest ferromagnetic or non-ferromagnetic grains present in the dune sand. The size of the coarsest titanomagnetic grain observed in the upper climbing dunes is represented by a mid-class diameter of $330 \mu \mathrm{m}$ (Fig. 7E). As these grains are spherical and well rounded, the weight of individual grain is equal to $0.09 \mathrm{~g}$ (Fig. 12). Pyroxene or amphibole grains of the same weight have a diameter of $380 \mu \mathrm{m}$ (Fig. 11), i.e., in the range of the coarsest size-class found in the dune deposits (Fig. 7D, E). The wind threshold shear velocity calculated from Bagnold formulae for grains of these diameters and densities equals between $0.31 \mathrm{~m} / \mathrm{s}$ (for pyroxene and amphibole) and $0.36 \mathrm{~m} / \mathrm{s}$ (for titanomagnetite), i.e., between 5.2 and $6.2 \mathrm{~m} / \mathrm{s}$ at a height of $10 \mathrm{~m}$, respectively. If we take into account the fact that the grains transported from the beach to the dune have to cross the zone of wind deceleration at the foot of the dune/cliff (Jackson and Hunt, 1975; Wiggs, 1993) the incident wind speed needs to be higher than above-mentioned values, and depends on incident wind angle, cliff slope and height (Piscioneri et al., 2019). Grains already entrained by wind are transported up the slope of climbing dune, because the impact threshold required to sustain aeolian movement of particles is equal to $80 \%$ of the fluid threshold (Andersson and Haff, 1988), and because it starts to experience higher speed, due to flow acceleration/velocity amplification (e.g., Wiggs, 1993; Soleimanian et al., 2019).

Second, how does the grain shape influence the critical threshold velocity and aeolian transport rate? At Patea, pyroxene or amphibole grains are often ellipsoidal, prismatic or elongated (Figs. 4 and 11), and therefore they are less prone to be mobilized by wind than rounded grains (Williams, 1964; Willets et al., 1982; Willets, 1983). On the other hand the largest grains (up to $500 \mu \mathrm{m}$ ) in the climbing dune sand are the most elongated amphibole grains, which indicates that such grains were entrained by aeolian transport. However, the effects of 

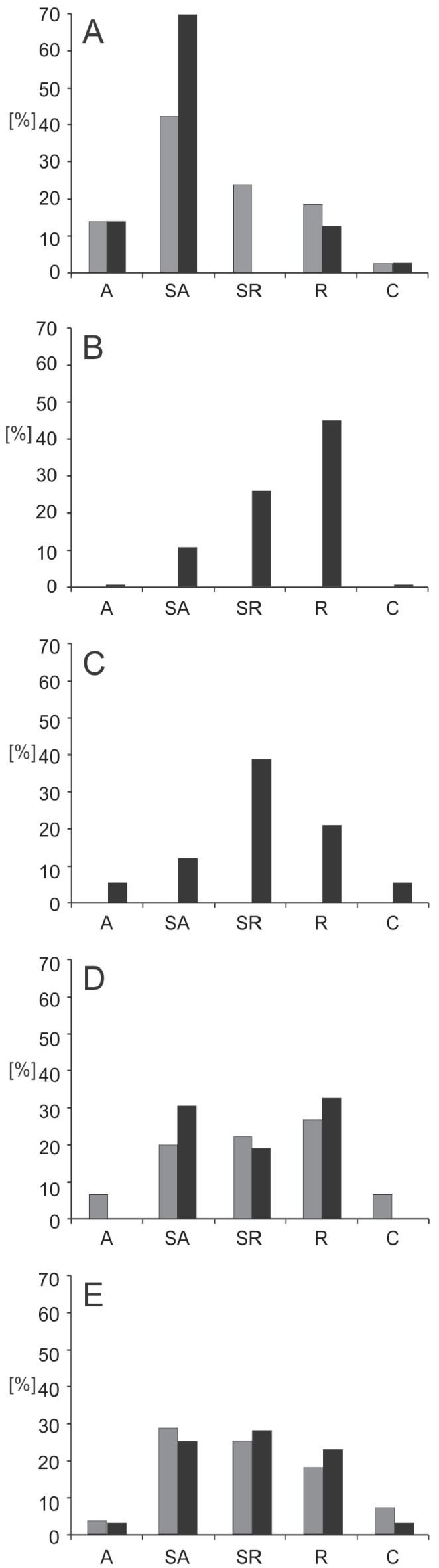

ferromagnetic $\square$ non-ferromagnetic grains grain shape are not yet incorporated in any of the existing aeolian transport formulae. Likewise, the effects of shape sorting during aeolian transport are also questionable. Research conducted mainly on quartz sand showed that spherical and rounded grains are preferentially transported by wind (e.g., MacCarthy, 1935; Shepard and Young, 1961; Mazzullo et al., 1986), but there were also studies showing the opposite trend (Winkenmolen, 1971; partly results of Willets at al., 1982) or else concluding that shape-sorting is of little importance (particularly in coastal areas; Mattox, 1955).

Third, why does sand sorting decreases downwind across beach-dune system and achieves the lowest value at the uppermost part of the climbing dune, exhibiting a pattern that is the reverse of that commonly accepted for quartz dune sand? For a dry bed composed of particles of uniform density, sorting by a moving air stream results mainly from wind energy and sorting of the source deposits. When wind energy increases, the size of particles in motion also increases. But if we take into account different heavy mineral grains (e.g., titanomagnetite and pyroxene or amphibole) of the same weight, i.e., different in size, the threshold shear velocity will be lower for grains of greater surface affected by wind. Thus, when the threshold velocity is between those for smaller and larger grains, only the larger grains are entrained by wind (Fig. 13). In consequence, beach sand composed of grains of different density and size is deprived of larger grains (pyroxene or amphibole). These grains are deposited within the lower part of the climbing dune due to flow deceleration. When wind accelerates up the climbing dune built of quartz grains, i.e., when wind energy increases, the size of particles up the dune slope also increases. But if we take into account different heavy mineral grains, the larger (and lighter) grains will be preferentially taken in motion and thus the grain size up the slope will decrease. Changes in sorting are also accompanied by a change in population skewness from positive at the upper beach, to slightly negative in the upper part of the climbing dune, both for ferromagnetic and non-ferromagnetic components. Shape sorting, which may occur after only a few metres of aeolian transport (Mazzullo et al., 1986), expressed by enrichment of dune sand with spherical and rounded grains, is not observed here.

Fourth, are there any additional factors that favour or constrain the aeolian sorting of heavy-mineral particles along the beach-dune transect? The dry swash zone (at low tide) comprises not only individual grains, but also grain aggregates, which are formed due to magnetic attraction (Fig. 5B-D) or are bound with salt (Fig. 5F). However, all aeolian deposits lack such aggregates. It suggests that they are either not movable, as they need proportionally higher wind fluid threshold to be moved, or they have undergone disaggregation due to bombarding by saltating grains or grain collision in a saltating cloud.

The results obtained from Patea Beach clearly demonstrate that grain weight is the main factor controlling aeolian sorting, with shape of secondary importance. However, all mentioned issues need further research, preferably based on field measurements of sand flux across the beach-dune system under different wind conditions.

Fig. 10. Roundness of ferromagnetic and non-ferromagnetic grains in sand samples

A - lower part of the swash zone (NZ1); B - the uppermost swash zone (NZ2); C - upper beach (NZ3); $\mathbf{D}$ - lower part of climbing dunes (NZ4); E - upper part of climbing dunes (NZ5); A - angular, SA - sub-angular, SR - sub-rounded, R - rounded, C - crushed 


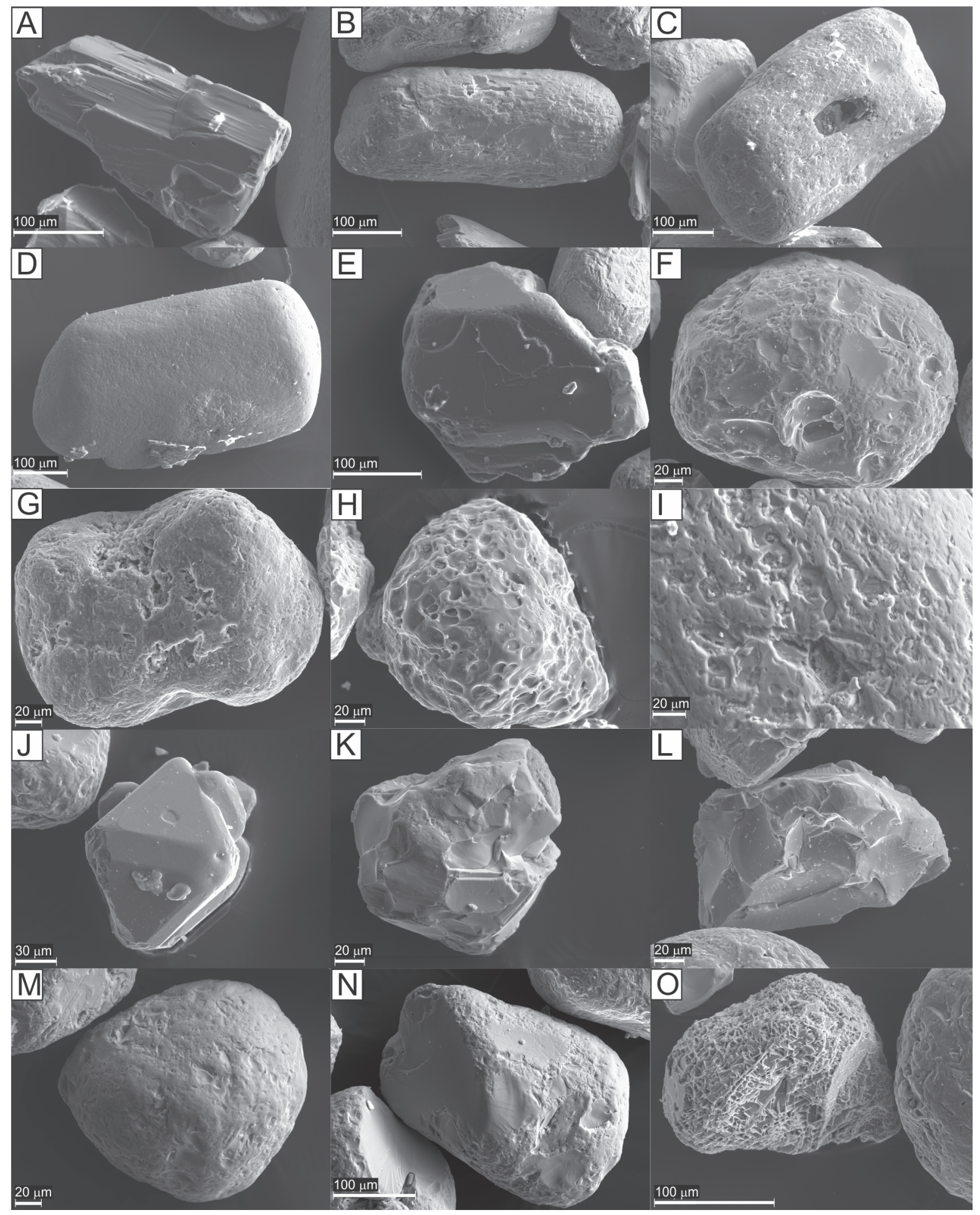

Fig. 11. SEM micrographs of sand-sized heavy mineral grains from Patea Beach

A - angular amphibole grain with single, shallow etch pits and sharp corners and edges; B, C - well-rounded amphibole grains with varied lenticular etch pits parallel to each other and fresh small conchoidal fractures; $\mathbf{D}$ - well-rounded pyroxene grain with smooth surface; $\mathbf{E}$ - angular pyroxene grain showing the effect of abrasion on corners; F - very well-rounded titanomagnetite grain with conchoidal fractures; $\mathbf{G}-$ very well-rounded titanomagnetite grain with a smooth surface on the edges and solution crevasses in depressions; $\mathbf{H}$-dissolved surface of a well-rounded titanomagnetite grain; $\mathbf{I}$ - a close up of a titanomagnetite grain with smooth surface and small conchoidal fractures showing the effect of abrasion; $\mathbf{J}$-octahedral titanomagnetite grain showing the effect of abrasion on corners; $\mathbf{K}$ - angular titanomagnetite grain with large, fresh conchoidal fractures; L - angular titanomagnetite grain with large, fresh conchoidal fractures; $\mathbf{M}$ - very well-rounded titanomagnetite grain with smooth surfaces and single conchoidal fractures; $\mathbf{N}$ - moderately-rounded titanomagnetite grain with abrasion on the corners and large conchoidal fractures; $\mathbf{O}$ - a very intensively weathered magnetite grain 


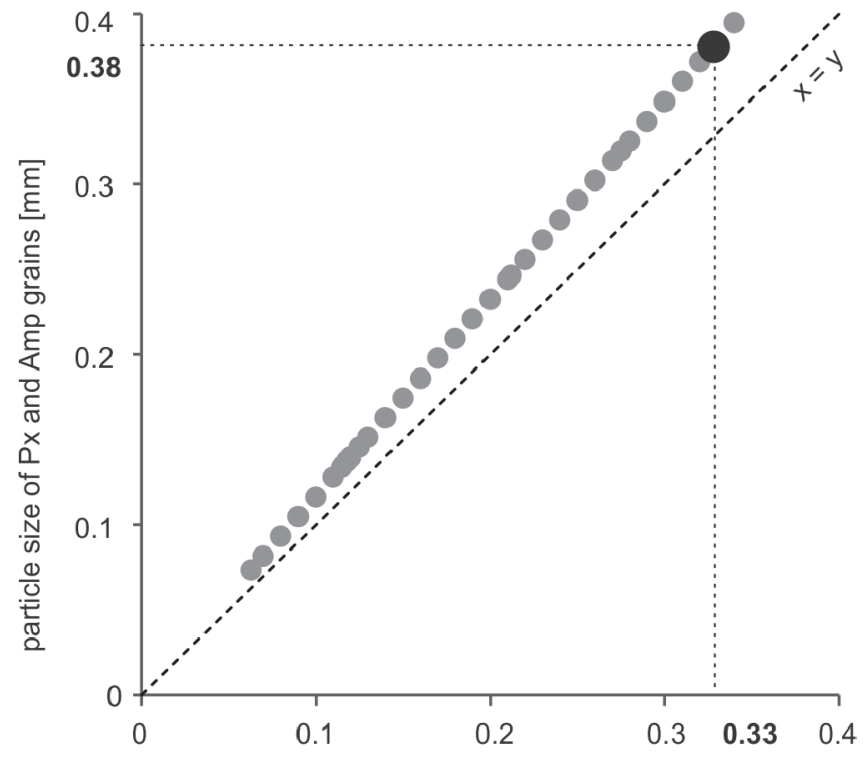

particle size of Tmt grains [mm]

Fig. 12. Particle size comparison of ferromagnetic (Tmt) and non-ferromagnetic (Px and Amp) grains of the same weight

Black dot marks the mid-point of the coarsest titanomagnetite grain class found in climbing dune sand and equivalent size of Px or Amp grain which in fact correspond to the coarsest size class of pyroxene and amphiboles; the weight of the marked grains is equal to $0.09 \mathrm{~g}$, as calculated for spherical grains

\section{ROUNDNESS AND MICROTEXTURE OF HEAVY MINERALS ALONG} THE PATEA BEACH DUNE SYSTEM

The high level of roundness, smooth surfaces, and a broad range of microtextures resulting from the dissolution and the visible features of abrasion at the edges, indicate grains were affected by long-term reworking in a water environment (Krinsley and Doornkamp, 1973; Berner and Schott, 1982; Mahaney, 2002; Velbel, 2007; Vos et al., 2014), although Costa et al. (2012) argued that short-lived but high energy events play even more important role in terms of the frequency and type of microtextural signatures. Moreover, abrasion and dissolution processes acted together and overprinting of microtextures occurred (for example, conchoidal fractures were dissolved and smooth surfaces were abraded). The differentiation of grain size, shape and roundness in water environments also reflects different resistance of particular minerals to weathering and abrasion resulting from their physicochemical properties such as hardness and cleavability (Komar, 2007).

According to Trenhaile et al. (1996), more rounded sand grains are deposited near the top of the uprush, while more angular grains remain in suspension and are carried back down the foreshore by the backrush. Our studies support this conclusion because the largest percentage of rounded and subrounded grains is recorded in the uppermost swash zone, whereas angular and subangular grains dominate in the lower part of the swash zone.

Grain abrasion and thus particle rounding during aeolian processes is a function of both grain size and wind velocity (Kuenen, 1960, 1964). Khalaf and Gharib (1985) found that the

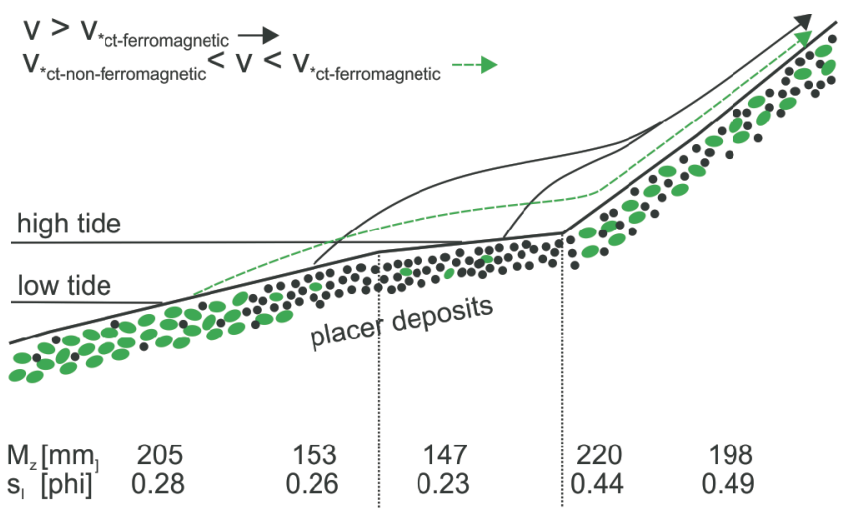

Weight percentage of ferromagnetic grains [wt.\%]

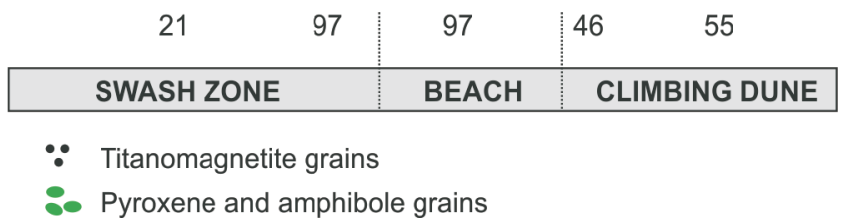

Fig. 13. Simple conceptual model of heavy mineral aeolian transport across beach-dune system at Patea

rate of abrasion decreases as grain size falls, although Thomas (1987) suggested that bigger or heavier grains are moved by creep and are probably subjected to less grain-upon-grain impacts than those mobilized by saltation, creating fewer opportunities for edge abrasion. The potential for abrasion of these grains may be further reduced by the likelihood that they are mobilized less often. Moreover, Folk (1978), working in the Simpson Desert, and Goudie and Watson (1981) in the Namib sand sea, found that even in areas offering the potential for sands to be reworked by the wind over a long period, grain roundness inherited characteristics from the parent material. However, the long-term aeolian abrasion would eliminate microtextures inherited from other environments (Szerakowska et al., 2018) and the surface of grains would exhibit one type of microtexture - mechanically upturned plates (Krinsley and Donahue, 1968; Krinsley and Doornkamp, 1973; Krinsley and McCoy, 1978; Mahaney, 2002; Vos et al., 2014).

In the case of Patea beach, the distance between the upper beach and the climbing dunes is too short for aeolian abrasion of grains. The presence of coarser grains of pyroxene and amphibole within the climbing dune sands also indicates that aeolian grain abrasion was too weak to decrease grain size. This result is consistent with Komar's (2007) observation and his conclusion that the propensity of such particles to fracture along cleavage planes during aeolian transport commonly results in the complete loss of the larger grains from the depositional system. Thus, the significant differences in grain roundness observed within the swash zone-beach-dune system (Fig. 9) results not from mechanical abrasion but from different mineral compositions.

The presence of fresh conchoidal fractures on the surface of titanomagnetite grains (Fig. 11F, K, L, N), overprinted by dissolution (Fig. 11L), confirms that the microtexture of the grains changed slightly along the studied transect. The most convex parts of the titanomagnetite grains were most exposed to abrasion (Fig. 11N). In contrast, no obvious aeolian imprints are observed on pyroxene and amphibole grains. 


\section{CONCLUSIONS}

Sand grain properties in different parts of the Patea swash zone-beach-dune system result from the resistance of particular minerals to weathering and abrasion, and to hydraulic sorting in the swash zone and aeolian sorting during grain transport inland from the upper beach. The main sand properties which evolve during these processes are mineralogy, grain size, shape and roundness. In the case of sand composed primarily of different heavy minerals, grains of high density are less likely to be transported and in consequence they are more or less represented in different parts of the swash zone-beach-dune system. As a result, three zones can be distinguished within this system: (1) lower part of the swash zone with the highest percentage of non-ferromagnetic lighter particles, (2) the uppermost swash zone and beach with almost $100 \%$ of ferromagnetic heavy particles, and (3) climbing dune composed of a mixture of both non- and ferromagnetic particles. In the first zone, the dominant pyroxene and amphibole grains are larger and more angular, and as having a lower density they are usually lighter than ferromagnetic grains. Thus they are carried back from the upper swash zone down the foreshore by the backwash. Heavier, but often smaller and more rounded titanomagnetite grains are deposited at the back of the beach by the swash, which during high tides and storms can reach the cliff toe. When the beach gets dry, wind strong enough may cause lighter particles to be removed from the beach, and transported up the cliff and accumulated within the dunes. Even if the grains have the same weight but - due to differences in density - different sizes, grains with greater diameter are moved first due to the larger surface exposed to the wind. A combination of these two processes results in grain segregation and consequently beach sand is more uniform in terms of both mineralogy and grain size and shape. A mixture of non- and ferromagnetic grains, with a very wide diversity of grain properties, is found in the third zone i.e. within the climbing dunes. The mineralogical heterogeneity of the sand source, mainly a large difference in particle density, produced by short-distance aeolian transport, is expressed here by decreased sand sorting and a wide range of grain shapes and roundness, opposite to the pattern in quartz-rich sands.

The results of this study are therefore helpful for a better understanding of depositional mechanisms in investigating ancient sedimentary successions. They also show that in the case of polymineral grain mixtures containing grains significantly different in density, grain size analysis of sand samples should be performed separately for particular groups of minerals. This is most important because the statistical parameters of grain size distribution obtained for raw samples may provide information which is misleading in interpreting the dynamics of different sedimentary processes.

Acknowledgements. This study was partially financed by the National Science Centre, Poland, project No. 2016/23/B/ST10/01700. The authors are particularly grateful to the Nano-Fun Laboratory at the Faculty of Geology, University of Warsaw, Poland, for the possibility of performing SEM analysis, J. Szmańda for the enabling us the use of Morphologi 3GDS and K. Krawczyk and K. Witkowski for performing analysis of grain shape using Morphologi 3GDS. Thanks to M. Kubiak for X-ray diffraction analysis and M. Nowak for assistance with the sand photos. We would like to thank R. Davidson-Arnott for comments on the first draft and R.L. Brathwaite and P.J.M. Costa for their insightful reviews.

\section{REFERENCES}

Abuodha, J.O.Z., 2003. Grain size distribution and composition of modern dune and beach sediments, Malindi Bay coast, Kenya. Journal of African Earth Sciences, 36: 41-54.

Achayra, B.C., Nayak, B.K., Das, S.K., 2009. Heavy mineral placer sand deposits of Kontiagarh area, Ganjam District, Orissa, India. Resource Geology, 59: 388-399.

Anderson, R.S., Haff, P.K., 1988. Simulation of eolian saltation. Science, 241: 820-823.

Angusamy, N., Dajkumar Sahayam, J., Suresh Gandhi, M., Victor Rajamanickam, G., 2005. Coastal placer deposits of central Tamil Nadu, India. Marine Georesources and Geotechnology, 23: 137-174.

Badesab, F., von Dobeneck, T., Bryan, K.R., Müller, H., Briggs, R.M., Frederichs, T., Kwoll, E., 2012. Formation of magnetite-enriched zones in and offshore of a mesotidal estuarine lagoon: An environmental magnetic study of Tauranga Harbour and Bay of Plenty, New Zealand. Geochemistry, Geophysics, Geosystems, 13: Q06012

Bagnold, R.A., 1941. The Physics of Blown Sand and Desert Dunes. Methuen, London.

Bagnold, R.A., 1966. An approach to the sediment transport problem from general physics. USGS Professional Paper, 442-J: $1-37$.

Bartzke, G., Schmeeckle, M.W., Huhn, K., 2018. Understanding heavy mineral enrichment using a three-dimensional numerical model. Sedimentology, 65: 561-581.

Bauer, B.O., Davidson-Arnott, R.G.D., 2002. A general framework for modelling sediment supply to coastal dunes including wind angle, beach geometry and fetch effects. Geomorphology, 49: 89-108.

Berner, R.A., Schott, J., 1982. Mechanism of pyroxene and amphibole weathering; II. Observations of soil grains. American Journal of Science, 282: 1214-1231.

Blott, S.J., Pye, K., 2001. GRADISTAT: a grain size distribution and statistics package for the analysis of unconsolidated sediments. Earth Surface Processes and Landforms, 26: 1237-1248.

Brathwaite, R.L., Gazley, M.F., Christie, A.B., 2017. Provenance of titanomagnetite in ironsands on the west coast of the North Island, New Zealand. Journal of Geochemical Exploration, 178: 23-34.

Brathwaite, R.L., Christie, A.B., Gazley, M.F., 2021. Stratigraphy, provenance and localisation of the titanomagnetite placer at Waikato North Head, South Auckland, New Zealand. Mineralium Deposita, 56: 343-362.

Briggs, R.M., Laurent, J.C., Hume, T.M., Swales, A., 2009. Provenance of black sands on the west coast, North Island, New Zealand. Proceedings of the 42nd AusIMM New Zealand Branch Annual Conference: 41-50.

Bryan, K.R., Robinson, A., Briggs, R.M., 2007. Spatial and temporal variability of titanomagnetite placer deposits on a predominantly black sand beach. Marine Geology, 236: 45-59.

Carter, L., 1980. Ironsand in continental shelf sediments off western New Zealand - a synopsis. New Zealand Journal of Geology and Geophysics, 23: 455-468.

Cascalho, J.P.V., Taborda, R.P.M., 2006. Heavy mineral placer formation an example from Algarve, Portugal. Journal of Coastal Research, SI 39: 246-249. 
Cascalho, J., Costa, P.J.M., Gelfenbaum, G., La Selle, S., Jaffe, B., 2020. Selective sediment transport during Hurricane Sandy on Fire Island (New York, USA). Journal of Sedimentary Research, 90: 269-285.

Cockayne, L., 1909. Report on the Sand Dunes of New Zealand: Their Geology and Botany, with their Economic Bearing. Department of Lands, Wellington, New Zealand.

Cockayne, L., 1911. Report on the Sand Dunes of New Zealand: Their Geology, Botany, and Reclamation. Department of Lands, Wellington, New Zealand.

Costa, P.J.M., Andrade, C., Dawson, A.G., Mahaney, W.C., Freitas, M.C., Paris, R., Taborda, R., 2012. Microtextural characteristics of quartz grains transported and deposited by tsunamis and storms. Sedimentary Geology, 275-276: 55-69.

Cox, S.H., 1881. Thames and Coromandel District. Report of Geological Survey of New Zealand, 40-1.

Davidson-Arnott, R.G.D., 2010. Introduction to Coastal Processes and Geomorphology. Cambridge University Press, Cambridge.

Dietrich, W.E., 1982. Settling velocity of natural particles. Water Resource Research, 18: 1615-1626.

Dłużewski, M., 2013. Morphology and morphodynamics of barchans in tropical regions (based on Sahara) (in Polish with English summary). Wyd. WGiSR UW, Warszawa.

Edgett, K.S., Lancaster, N., 1993. Volcaniclastic aeolian dunes: Terrestrial examples and application to Martian sands. Journal of Arid Environments, 25: 271-297.

Folk, R.L., 1978. Angularity and silica coatings of Simpson Desert sand grains, Northern Territory Australia. Journal of Sedimentary Petrology, 48: 611-624.

Folk, R.L., Ward, W.C., 1957. Brazos River bar: a study in the significance of grain size parameters. Journal of Sedimentary Petrology, 27: 3-26.

Fryberger, S.G., Dean, G., 1979. Dune forms and wind regime. U.S. Geological Survey, Washington, Professional Paper, 1052: 137-169.

Gorman, R.M., Bryan, K.R., Laing, A.K., 2003. A wave hindcast for the New Zealand region - deep-water wave climate. New Zealand Journal of Marine and Freshwater Research, 37: 589-612.

Goudie, A.S., Watson, A., 1981. The shape of desert sand grains. Journal of Arid Environments, 4: 185-190.

Gow, A.G., 1967. Petrographic studies of iron sands and associated sediment near Hawera, South Taranaki. New Zealand Journal of Geology and Geophysics, 10: 675-696.

Gow, A.J., 1968. Petrographic and petrochemical studies of Mt Egmont andesites. New Zealand Journal of Geology and Geophysics, 11: 166-190.

Garzanti, E., Ando, S., Vezzoli, G., 2008. Settling equivalence of detrital minerals and grain-size dependence of sediment composition. Earth and Planetary Science Letters, 273: 138-151.

Hand, B.M., 1967. Differentiation of beach and dune sands, using settling velocities of light and heavy minerals. Journal of Sedimentary Petrology, 37: 514-520.

Hartmann, D., 1991. Cross-shore selective sorting processes and grain-size distributional shape. Acta Mechanica, 2: 49-63.

Houser, C., 2009. Synchronization of transport and supply in beach-dune interaction. Progress in Physical Geography, 33: 733-746.

Hume, T., Ovenden, R., MacDonald, I., 2012. Coastal stability in the South Taranaki Bight - Phase 1. Historical and present day shoreline change. NIWA Client Report No HAM2012-083.

Jackson, P.S., Hunt, J.C.R., 1975. Turbulent wind flow over a low hill. The Quarterly Journal of the Royal Meteorological Society, 101: 929- 955.

Kasper-Zubillaga, J.J., Carranza-Edwards, A., Morton-Bermeaet, O., 2008. Heavy minerals and rare earth elements in coastal and inland dune sand of Vizcaino Desert, Baja California Peninsula, Mexico. Marine Georesources and Geotechnology, 2: 172-188.

Kear, D., 1965. Geology of New Zealand's ironsand resources. Proceedings of the 8th Commonwealth Mining and Metallurgical Congress, New Zealand Section, paper 219.
Kear, D., 1979. Geology of ironsand resources of New Zealand. DSIR, Wellington.

Khalaf, F.L., Gharib, I.M., 1985. Roundness parameters of quartz sand grains of recent aeolian sand deposits in Kuwait. Sedimentary Geology, 45: 137-158.

Komar, P.D., 1987. Selective grain entrainment by a current from a bed of mixed sizes: a reanalysis. Journal of Sedimentary Petrology, 57: 203-211.

Komar, P.D., 1989. Physical processes of waves and currents and the formation of marine placers. CRC Critical Reviews in Aquatic Sciences, 1: 393-423.

Komar, P.D., 2007. The entrainment, transport and sorting of heavy minerals by waves and currents. Developments in Sedimentology, 58: 3-48.

Komar, P.D., Reimers, C.E., 1978. Grain shape effects on settling rates. Journal of Geology, 86: 193-209.

Komar, P.D., Wang, C., 1984. Processes of selective grain transport and the formation of placers on beaches. Journal of Geology, 92: 637-655.

Krinsley, D.H., Donahue, J., 1968. Environmental interpretation of sand grain surface textures by electron microscopy. GSA Bulletin, 79: 743-748.

Krinsley, D.H., Doornkamp, J.C., 1973. Atlas of Quartz Sand Surface Textures. Cambridge University Press, Cambridge.

Krinsley, D.H., McCoy, F., 1978. Aeolian quartz sand and silt. In: Scanning Electron Microscopy in the Study of Sediments - a Symposium Geo Abstracts (ed. W.B. Whalley): 249-260. Norwich.

Kuenen, Ph.H., 1960. Experimental abrasion. 4. Eolian action. Journal of Geology, 68: 427-449.

Kuenen, Ph.H., 1964. Experimental abrasion: 6. Surf action. Sedimentology, 3: 29-43.

Li, M.Z., Komar, P.D., 1992. Selective entrainment and transport of mixed size and density sands: experiments simulating the formation of black-sand placers. Journal of Sedimentary Petrology, 62: $584-590$.

MacCarthy, G.R., 1935. Eolian sands, a comparison. American Journal of Science, 30: 81-95.

Mahaney, W.C., 2002. Atlas of Sand Grain Surface Textures and Applications. Oxford University Press.

Mange, M.A., Maurer, H.F.W., 1992. Heavy Minerals in Colour. Chapman \& Hall, London.

Mattox, R.B., 1955. Eolian shape sorting. Journal of Sedimentary Petrology, 25: 111-114.

Mazzullo, J., Sims, D., Cunningham, D., 1986. The effects of eolian sorting and abrasion upon the shapes of fine quartz sand grains. Journal of Sedimentary Petrology, 56: 45-56.

McGlone, M.S., Neal, V.E., Pillans, B.J., 1984. Inaha Terrace deposits: a late Quarternary terrestrial record in South Taranaki, New Zealand. New Zealand Journal of Geology and Geophysics, 27: 35-49.

Mead, S., 2013. Potential effects of Trans-Tasman Resources Mining Operations on surfing breaks in the Southern Taranaki Bight. Report for NIWA Taihoro Nukurangi, eCoast Ltd.

Morgan, P.G., Gibson, W., 1927. The geology of the Egmont subdivision. Bulletin of Geological Survey of New Zealand: 1-29.

Morphologi G3 User Manual 0140, 2008. Malvern Instruments Ltd., Worcestershire, Great Britain.

Muckersie, C., 1989. The location and orientation of coastal parabolic sand dunes in New Zealand. MSc. Thesis, Massey University, Palmerston North.

Neall, V.E., Stewart, R.B., Smith, I.E.M., 1986. History and petrology of the Taranaki volcanoes. Royal Society of New Zealand Bulletin, 23: 251-263.

Nicholson, D.S., Fyfe, H.E., 1958. Borehole survey of North Island ironsands from New Plymouth to Kaipara Harbour. New Zealand Journal of Geology and Geophysics, 1: 617-634.

Pickerill, R.A., Mitchel, J.S., 1979. Ocean wave characteristic around New Zealand. New Zealand Journal of Marine and Freshwater Research, 13: 501-520. 
Pillans, B.J., 1990. Late Quaternary marine terraces, south Taranaki-Wanganui. New Zealand Geological Survey miscellaneous series map 18.

Piscioneri, N., Smyth, T.A.G., Hesp, P.A., 2019. Flow dynamics over a foredune scarp. Earth Surface Processes and Landforms, 44: 1064-1076.

Poché, D., Goodell, H.G., 1975. Influence of grain shape on the selective sorting of sand by waves. GSA Memoir, 142: 137-148.

Pupienis, D., Buynevich, I.V., Bitinas, A., 2011. Distribution and significance of heavy-mineral concentrations along the southeast Baltic Sea coast. Journal of Coastal Research, SI 64: 1984-1988.

Rao, C.B., 1957. Beach erosion and concentration of heavy mineral sands. Journal of Sedimentary Petrology, 27: 143-147.

Reichelt, G., 1961. Über Schotterformen und Rundungsgradanalyse als Feldmethode. Petermanns Geographische Mitteilungen, 105: 15-24.

Schmidt, R.G., Asad, S.A., 1962. Beach placers containing radioactive minerals, Bay of Bengal, East Pakistan. U.S. Geological Survey Research, 450: 12-14.

Schuiling, R.D., de Meijer, R.J., Riezebos, H.J., Scholten, M.J., 1985. Grain size distribution of different minerals in a sediment as a function of their specific density. Geologie en Mijnbouw, 64: 199-203.

Shepard, F.P., Young, R., 1961. Distinguishing between beach and dune sands. Journal of Sedimentary Petrology, 31: 196-214.

Shepherd, M., Hesp, P., 2003. Sandy barriers and coastal dunes In: The New Zealand Coast, Te Tai Aotearoa (eds. J.R. Goff, S.L. Nichol and H.L. Rouse): 163-189. Dunmore Press, New Zealand.

Shields, A., 1936. Anwendung der Aehnlichkeitsmechanik und der Turbulenzforschung auf die Geschiebebewegung. Mitteilungen der Preussischen Versuchsanstalt für Wasserbau und Schiffbau, 26

Slingerland, R., 1984. Role of hydraulic sorting in the origin of fluvial placers. Journal of Sedimentary Petrology, 54: 137-150.

Slingerland, R., Smith, N.D., 1986. Occurrence and formation of water-laid placers. Annual Review of Earth and Planetary Sciences, 14: 113-147.

Soleimanian, M., Kilanehei, F., Memarpour, M., 2019. Comparison of wind speed-up over escarpments derived from numerical modelling and wind-loading codes. Journal of Civil Engineering, 3: 75-84.

Stewart, R.B., Price, R.C., Smith, I.E.M., 1996. Evolution of high-K arc magma, Egmont volcano, Taranaki, New Zealand: evidence from mineral chemistry. Journal of Volcanology and Geothermal Research, 74: 275-295.

Summerhayes, C.P., 1967. Marine environments of economic mineral deposition around New Zealand: a review. New Zealand Journal of Marine and Freshwater Research, 1: 267-282.
Szerakowska, S., Woronko, B., Sulewska, M.J., Oczeretko, E., 2018. Spectral method as a tool to examine microtextures of quartz sand-sized grains. Micron, 110: 36-45.

Szmańda, J.B., Witkowski, K., Chmielowska, D., Smolska, E., Szwarczewski, P., 2018. Analiza graniformametryczna obtoczenia ziaren kwarcu w świetle parametrów uzyskiwanych aparatem Morphologi G3 (in Polish). In: Geneza, litologia i stratygrafia utworów czwartorzędowych (eds. A. Kostrzewski, A. Stach and M. Majewski), VII: 191-195. IGIG UAM, Poznań.

Thomas, D.S.G., 1987. The roundness of aeolian quartz sand grains. Journal of Sedimentary Petrology, 52: 149-153.

Thomson, J.A., 1917. The Hawera series or the so-called "Drift Formation" of Hawera. Transactions and Proceedings of the Royal Society of New Zealand, 49: 414-417.

Trask, C.B., Hand, B.M., 1985. Differential transport of fall-equivalent sand grains, Lake Ontario, New York. Journal of Sedimentary Petrology, 55: 226-234.

Trenhaile, A.S., Van der Nol, L.V., La Valle, P.D., 1996. Grain roundness and beach sorting. Journal of Coastal Research, 12: 1017-1023.

Turner, M.B., Cronin, S.J., Bebbington, M., Smith, I.E.M., Stewart, R.B., 2011. Integrating records of explosive and effusive activity from proximal and distal sequences: Mt. Taranaki, New Zealand. Quaternary International, 246: 364-373.

Velbel, M.A., 2007. Surface textures and dissolution processes of heavy minerals in the sedimentary cycle: examples from pyroxenes and amphiboles. Developments in Sedimentology, 58: 113-150.

Vos, K., Vandenberghe, N., Elsen, J., 2014. Surface textural analysis of quartz grains by scanning electron microscopy (SEM): From sample preparation to environmental interpretation. Earth-Science Reviews, 128: 93-104.

Wiggs, G.F.S., 1993. Desert dune dynamics and the evaluation of shear velocity: an integrated approach. Geological Society Special Publications, 72: 37-48.

Willets, B., 1983. Transport by wind of granular materials of different grain shapes and densities. Sedimentology, 30: 669-679.

Willets, B.B., Rice, M.A., Swaine, S.E., 1982. Shape effects in aeolian grain transport. Sedimentology, 19, 409-417.

Williams, S.H., 1964. Some aspects of the aeolian saltation load. Sedimentology, 3: 257-287.

Winkelmolen, A.M., 1971. Rollability, a functional shape property of sand grains. Journal of Sedimentary Petrology, 41: 703-714.

Wu, W., Wang, S.S.Y., 2006. Formulas for sediment porosity and settling velocity. Journal of Hydraulic Engineering, 132: 858-862.

Zernack, A.V., Price, R.C., Smith, I.E.M., Cronin, S.J., Stewart, R.B., 2012. Temporal evolution of high-K andesitic magmatic system: Taranaki Volcano, New Zealand. Journal of Petrology, 53: 325-363. 